\title{
Performance of Plastic Mulch on Papaya Crop
}

\author{
K.K. Sakariya*, R.M. Satasiya, V.D. Satasiya and P.S. Sapariya \\ College of Agricultural Engineering and Technology, JAU, Junagadh-362001, Gujarat, India \\ *Corresponding author
}

\begin{tabular}{|c|c|}
\hline \multicolumn{2}{|r|}{ A B S T R A C T } \\
\hline & \multirow{5}{*}{$\begin{array}{l}\text { The experiment on performance of plastic mulch on papaya crop was carried out for two } \\
\text { varieties Madhubindu and Taiwan. Papaya had grown under mulch (silver black plastic } \\
\text { mulch and black plastic mulch) and no mulch condition in JAU, Junagadh (Gujarat). } \\
\text { Randomized Block Design with four replications was selected for the experiment. Crop } \\
\text { water requirement was estimated by Penman-Monteith method. Soil parameter (moisture } \\
\text { and Temperature) and crop parameter (plant height, stem diameter, number of leaves, } \\
\text { number of flowers and number of fruits) were recorded and analysed the effect on papaya } \\
\text { crop. The maximum plant height (1.50m), stem diameter }(84.30 \mathrm{~mm}) \text {, number of leaves } \\
\text { (31.50), number of flowers }(9.60) \text {, number of fruits }(10.30) \text { were observed in silver black } \\
\text { plastic mulch and all these parameters were found minimum under no mulch condition. } \\
\text { The maximum soil moisture ( } 20.68 \%) \text { was found in silver black plastic mulch and it was } \\
\text { minimum in no mulch condition. Water saving was found as } 31.75 \% \text { in mulch condition } \\
\text { as compared to no mulch condition. For Madhubindu variety, the maximum benefit cost } \\
\text { ratio ( } 8.70) \text { and maximum net income ( } 702509.55 \text { Rs/ha) was found as in silver black } \\
\text { plastic mulch For Taiwan variety, the maximum benefit cost ratio }(9.30) \text { and maximum net } \\
\text { income ( } 758509.55 \mathrm{Rs} / \mathrm{ha} \text { ) was found as in silver black plastic mulch. }\end{array}$} \\
\hline & \\
\hline Article & \\
\hline & \\
\hline & \\
\hline
\end{tabular}

\section{Introduction}

Agriculture contributes more than $70 \%$ of water utilization worldwide and $90 \%$ of water utilization in the developing countries. India accounts for the $16 \%$ of the world's human population and nearly $30 \%$ of the cattle with only $2.4 \%$ of the land and $4 \%$ of the water resources. Gujarat is the extreme western state of India with having an area of 19.6 Mha, representing $6 \%$ of the total area of the country. Gujarat state has 33\% irrigated area, out of 10.7 Mha of cultivable land. As compared to the surface water, greater proportion of additional irrigation water comes from the ground water and this source is increasingly being exploited in an unscientific manner. Land and water are the basic inputs of agricultural and economic development of any country. Demand of these resources is continuously increasing. Therefore, it becomes necessary to utilize these resources judiciously, to full fill the demand of irrigation water. The irrigation efficiency can be enhanced by replacing surface irrigation with micro irrigation methods especially in arid and semiarid regions. The overall irrigation efficiency of micro irrigation methods normally ranges from 70 to $90 \%$ as compared to 30 to $45 \%$ in 
case of surface irrigation owing to reduced loss of moisture through evaporation and runoff(Agrawal 2005). Mulching is the process or practice of covering the soil/ground to make more favourable condition for plant growth, development and efficient crop production. According to other mulches plastic mulches are completely impermeable to water; therefore it prevents direct evaporation of moisture from the soil and thus it reduce the water losses and soil erosion over the surface. Plastic film with its moisture barrier properties does not allow the soil moisture to escape water that evaporates from the soil surface under mulch film, condenses on the lower surface of the film and falls back as droplets. Thus moisture is preserved for several days and increases the period between two irrigations (Anonymous, 2014; Biswas et al., 2015).

Fruits and their culture have very close association with life of man. Human civilization linked with development of fruit industry. Role of fruits which are widely called as 'protective food' in human diet, is well known from the prehistoric era. In the galaxy of fruit crops, papaya is dominating fruit crop. The papaya is the fruit of the plant carica papaya, the sole species in the genus carica of the plant family Caricaceae. Papaya is a tropical plant, very sensitive to frost. Optimum temperature for papaya is $25-30{ }^{\circ} \mathrm{C}$ and minimum $16^{\circ} \mathrm{C}$. The suitable $\mathrm{pH}$ value is between 6 and 6.5. The well drained or sandy loam soil with adequate organic matter is the most important for the papaya cultivation. The major papaya producing belts in India are Andhara Pradesh 27.1\%, Gujarat 23.2\%, Maharashtra 7.6\%, Karnataka 10.5\%, Madhya Pradesh 5.4\%, West Bengal 7.7\%, Assam $3.2 \%$ and Orissa having ideal climatic conditions for its growth and production. (Anonymous, 2010b; Masri and Razak (1990); Suresh R. and Saha, D. P. (2004). Considering the current constraints of limited availability of irrigation water in Saurashtra region, adoption of plastic mulch for the papaya crop will be a solution to increase the water use efficiency. So, it is present need to work out suitable colour of plastic mulch for papaya cultivation.

\section{Materials and Methods}

To evaluate the performance of papaya crop in different colour plastic mulch (silver-black, black and no mulch) and irrigation was carried out by drip irrigation method. In Drip irrigation system the drip line, drip discharge and space between two drippers is $16 \mathrm{~mm}, 2$ lph, and $40 \mathrm{~cm}$ respectively (Cetin and Uygan, 2008; Deshmukh and Hardaha, 2014). Experiment was conducted at the RE and RE Department, Collage of Agricultural Engineering and Technology, JAU, Junagadh (Gujarat), India. During August 2016 to December 2016. Two types of varieties (Madhubindu and Taiwan) and three types of mulch treatment (silver-black, black and no mulch) were considered for the study. The experimental design was randomized block design with four replication and each treatment having four plants. One planting was considered as one replication for every plant parameter (Ghanshyam Deshmukh and Hardaha, 2014; Hamid, 2010).

For bed preparation, the entire field was ploughed and harrowed to facilitate deeper rooting once to a depth of $30 \mathrm{~cm}$ and moisture penetration. Plots were marked out and made 2 beds of $23 \mathrm{~m}$ length, top width of $0.55 \mathrm{~m}$, bottom width of $0.80 \mathrm{~m}$ and height of $0.15 \mathrm{~m}$. plant to plant distance was $1.5 \mathrm{~m}$, and row to row distance was $1.8 \mathrm{~m}$ by manually. According to treatment, plastic mulch was laid on the bed manually. Soil moisture and temperature recorder was installed for recording of the soil moisture and soil temperature respectively. The soil moisture sensors were soaked overnight in water, dried 
it until evening, again wet for 30 minutes and dried overnight. Sensors holes were made with auger and placed sensors at depth $5 \mathrm{~cm}$ from top of the soil. The holes were filled with water and soil slurry to removed air pockets.

Preparation of papaya seedling; Soil, sand and FYM were used for the root media preparation and its proportion was kept as 1:1:1. Root media was filled up in black soft polythene bag of 40 micron having dimension of $5 \mathrm{~cm} \times$ $20 \mathrm{~cm}$.

After a Sowing of Madhubindu and Taiwan papaya seeds Irrigation was applied manually through the garden shower. Up to the one month, irrigation was applied daily and after that it was applied alternate day. Recommended insecticides and pesticides were used according to pests and dieses infestations. Papaya seedlings were transplanted in the field manually directly at the hole made on the mulch film.

\section{Calculation of Irrigation Requirement}

A popular method used to estimate $\mathrm{ET}_{\mathrm{c}}$ is the crop coefficient $\left(\mathrm{K}_{\mathrm{c}}\right)$. In this approach, irrigation requirement for papaya was determined by Penman-Monte $\mathrm{i}^{\text {th }}$ method (Allen et al., 1998).

\section{Total irrigation water requirement}

The total irrigation water requirement as per irrigation level was calculated below:

$\mathrm{IW}=\mathrm{L} \times \mathrm{ET}_{\mathrm{c}}(1)$

Where, IW = Depth of water to be applied (mm). $\mathrm{L}=$ level of irrigation $(\mathrm{L}=1$ i.e. $100 \%$ of crop water requirements). ETc $=$ crop evapotranspiration (mm/day). ETc = cumulative crop evapotranspiration from day of preceding irrigation (Doorenbos and Pruitt, 1977).

\section{Results and Discussion}

Soil parameters like soil temperature and soil moisture was recorded by soil moisture and temperature data logger in which soil temperature and soil moisture recorded automatically. Plant height from each treatment was measured using scale in meter at 30, 60, 90 and 120 days after planting (DAP) and mean number of plant height was calculated. Number of leaves, number of flowers, number of fruits, per plant in each treatment was counted at 30, 60, 90 and 120 days after planting (DAP) and mean number of leaves per plant, mean number of flowers, mean number of fruits was calculated. Stem diameter from each treatment was measured using scale in milli meter at 30,60, 90,120 and 150 days after the transplanting.

The crop yield was obtained for each treatment and was divided by the quantity of water use consumptively for the respective treatments. Water use efficiency was worked out and expressed in $\mathrm{kg}$ per ha-mm of water use.

WUEij = Ygij/Wij (2)

WUEij = Water use efficiency of papaya under treatment and replication, (kg/ha.mm).

Ygij = Yield of papaya under treatment and replication, $(\mathrm{kg} / \mathrm{ha})$.

Wij = Seasonal irrigation water applications in treatment and replication, (mm).

\section{Results and Discussion}

\section{Estimation of crop water requirement}

$\mathrm{K}_{\text {Cini }}$ for drip irrigated papaya crop without mulch was 0.86 as per equation. FAO 56 suggested $\mathrm{K}_{\mathrm{Cmid}}$ and $\mathrm{K}_{\text {Cend }}$ values for papaya crop were 1.05 and 0.85 respectively. These 
values were corrected for local conditions as per the procedure suggested by FAO 56 using equation. $\mathrm{K}_{\text {Cini }}$ for drip irrigated papaya crop with mulch was 0.1 as per FAO 56. The corrected values of $\mathrm{K}_{\mathrm{Cmid}}$ and $\mathrm{K}_{\text {Cend }}$ for plastic mulch were 0.94 and.60 respectively (Fig. 1).

\section{Irrigation requirement in papaya crop}

In month of September depth of irrigation in mulch and no mulch condition was $9.33 \mathrm{~mm}$ and $90.39 \mathrm{~mm}$ respectively. Irrigation time was $0.18-9.56 \mathrm{~min} /$ day and $0.18-86.66$ $\mathrm{min} /$ day respectively. In month of October depth of irrigation in mulch and no mulch condition was $82.05 \mathrm{~mm}$ and $99.84 \mathrm{~mm}$ respectively. Irrigation time was $0.36-70.63$ $\mathrm{min} /$ day and $0.18-75.60 \quad \mathrm{~min} /$ day respectively.

In month of November, depth of irrigation in mulch and no mulch condition was $90.09 \mathrm{~mm}$ and $100.49 \mathrm{~mm}$ respectively. Irrigation time was $0.36-62.75 \mathrm{~min} /$ day and $52.89-69.35$ min/day respectively. In month of November depth of irrigation in mulch and no mulch condition was $75.12 \mathrm{~mm}$ and $95.07 \mathrm{~mm}$ respectively. Irrigation time was $29.39-61.45$ $\mathrm{min} /$ day and $41.85-88.13 \mathrm{~min} /$ day respectively.

\section{Crop parameter}

Crop parameter was measured such as plant height, stem diameter, no. of leaves, no. of flower, no. of fruits after 30 days, 60 days, 90 days and120 days respectively.

\section{Plant height}

The results of analysis of variance presented that effect of mulches and variety in figure 2 . The treatment M1 (silver black plastic mulch) gave maximum plant height of papaya as $1 \mathrm{~m}$, $1.2 \mathrm{~m}, 1.4 \mathrm{~m}$, and $1.5 \mathrm{~m}$ at 30, 60, 90, and 120 DAP (Day after plantation) respectively. The treatment M3 (no mulch) gave minimum plant height of papaya as $0.8 \mathrm{~m}, 1.00 \mathrm{~m}, 1.10 \mathrm{~m}$ and $1.30 \mathrm{~m}$ for $30,60,90$ and 120 DAP respectively.

\section{Stem diameter}

The data on stem diameter of papaya at different time period was influenced by mulch and variety are presented in figure 3 . The treatment M1 (silver black plastic mulch) gave maximum stem diameter of papaya as 59.0 $\mathrm{mm}, 69.30 \mathrm{~mm}, 77.90 \mathrm{~mm}$, and $84.30 \mathrm{~mm}$ at 30, 60, 90, and 120 DAP respectively. The treatment M3 (no mulch) gave minimum stem diameter of papaya as $48.30 \mathrm{~mm}, 59.00 \mathrm{~mm}$, $65.50 \mathrm{~mm}$ and $73.80 \mathrm{~mm}$ for $30,60,90$ and 12.

\section{No. of leaves}

The data on no. of leaves of papaya plant at different period was influenced by mulch and variety are presented in figure 4. The treatment M1 (silver black plastic mulch) gave maximum no. of leaf of papaya as 19.10, $19.00,25.80$ and 31.50 at 30,60, 90, and 120 DAP respectively.

The treatment M3 (no mulch) gave minimum no. of leaf of papaya as 12.6, 14.10, 16.60 and 18.30 for $30,60,90$ and 120 DAP respectively.

\section{No. of flowers}

The data on no. of flower of papaya plant at different period was influenced by mulch and varieties are presented in figure 5. The treatment M1 (silver black plastic mulch) gave maximum no. of flower of papaya as 9.00 , $8.00,8.30$ and 9.60 at 30, 60, 90, and 120 DAP respectively. The treatment M3 (no mulch) gave minimum no. of flower of papaya as 6.00, 5.50, 6.60 and 5.80 for 30, 60, 90 and 120 DAP respectively. 
Table.1 Effect of mulching on water use efficiency

\begin{tabular}{|c|c|c|c|c|c|c|}
\hline $\begin{array}{l}\text { Variet } \\
\mathbf{y}\end{array}$ & \multicolumn{2}{|c|}{ Treatments } & $\begin{array}{l}\text { Mean } \\
\text { yield, } \\
\text { kg/ha }\end{array}$ & $\begin{array}{c}\text { Irrigation } \\
\text { depth, } \\
\text { mm }\end{array}$ & $\begin{array}{c}\text { WUE, } \\
\text { kg/ha.mm }\end{array}$ & $\begin{array}{l}\text { Water saving } \\
\text { as compare to } \\
\text { no mulch, } \%\end{array}$ \\
\hline \multirow{3}{*}{$\begin{array}{l}\text { Madhu } \\
\text { bindu }\end{array}$} & \multirow[b]{2}{*}{$\begin{array}{l}\text { Mulch } \\
\text { condition }\end{array}$} & $\begin{array}{l}\text { Silver black } \\
\text { plastic Mulch }\end{array}$ & 78400 & 234.71 & 334.03 & \multirow[b]{2}{*}{31.75} \\
\hline & & $\begin{array}{l}\text { Black plastic } \\
\text { mulch }\end{array}$ & 70000 & 234.71 & 298.24 & \\
\hline & \multicolumn{2}{|l|}{ No mulch } & 56000 & 343.9 & 162.12 & \\
\hline \multirow{3}{*}{$\begin{array}{c}\text { Taiwa } \\
\text { n }\end{array}$} & \multirow[b]{2}{*}{$\begin{array}{l}\text { Mulch } \\
\text { condition }\end{array}$} & $\begin{array}{l}\text { Silver black } \\
\text { plastic Mulch }\end{array}$ & 84000 & 234.71 & 357.88 & \multirow[b]{2}{*}{31.75} \\
\hline & & $\begin{array}{l}\text { Black plastic } \\
\text { Mulch }\end{array}$ & 75600 & 234.71 & 322.1 & \\
\hline & \multicolumn{2}{|l|}{ No mulch } & 61600 & 343.9 & 179.12 & \\
\hline
\end{tabular}

Table.2 Cost economics of papaya crop by using mulching

\begin{tabular}{|l|l|l|l|l|l|l|l|l|l|l|}
\hline Treatments & $\begin{array}{l}\text { Material } \\
\text { required } \\
\text { (kg/ha) }\end{array}$ & $\begin{array}{l}\text { Material } \\
\text { cost } \\
\text { (Rs/ha) }\end{array}$ & $\begin{array}{l}\text { Total cost of } \\
\text { mulching } \\
\text { (Rs/ha) }\end{array}$ & Yield (kg/ha) & $\begin{array}{l}\text { Gross } \\
\text { (Rs/ha) }\end{array}$ & return & \multicolumn{2}{l}{$\begin{array}{l}\text { Net return } \\
\text { (Rs/ha) }\end{array}$} \\
\hline $\begin{array}{l}\text { Silver black } \\
\text { plastic mulch }\end{array}$ & 276 & 28980 & 16874.23 & 78400 & 84000 & 784000 & 840000 & 702509.55 & 758509.55 \\
\hline $\begin{array}{l}\text { Black plastic } \\
\text { mulch }\end{array}$ & 217 & 43400 & 47706 & 70000 & 75600 & 700000 & 756000 & 587677.80 & 643677.80 \\
\hline
\end{tabular}

Note: price of silver black plastic mulch $=105 \mathrm{Rs} / \mathrm{kg}$; price of black plastic mulch $=200 \mathrm{Rs} / \mathrm{kg}$; sale price of papaya $=10 \mathrm{Rs} / \mathrm{kg}$.

Fig.1 Adjusted crop coefficient curve of $\mathrm{K}_{\mathrm{C}} \mathrm{FAO}, \mathrm{K}_{\mathrm{C}}$ no mulch and $\mathrm{K}_{\mathrm{C}}$ mulch

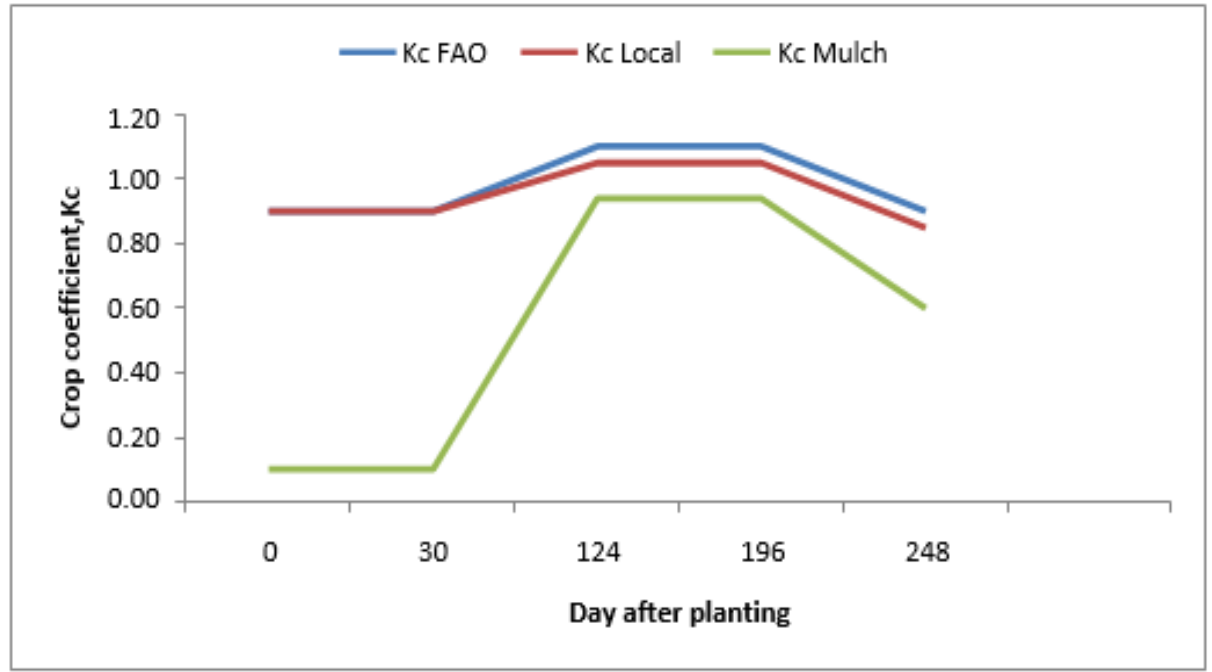


Fig.2 Height of papaya in different mulch

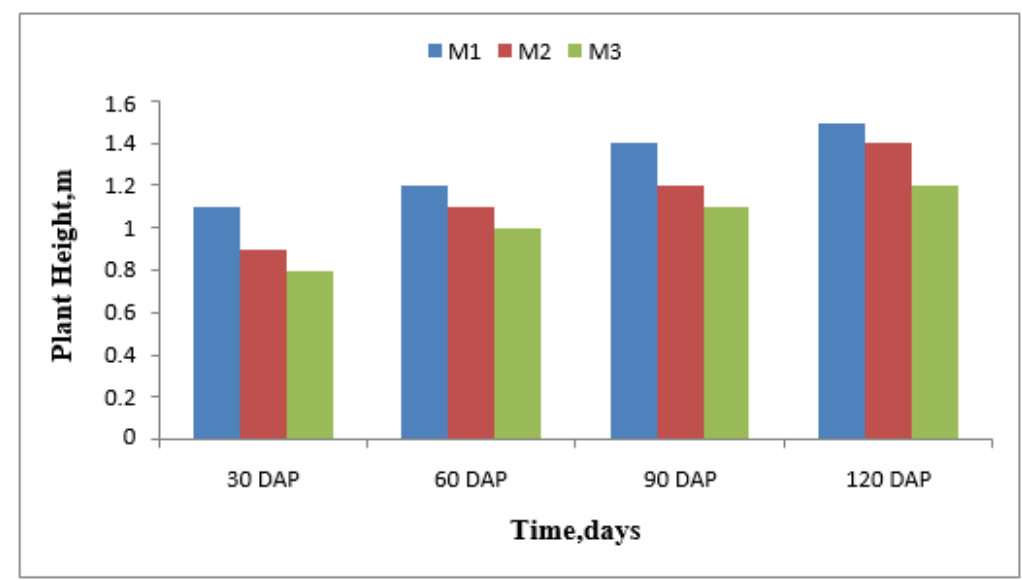

Fig.3 Stem diameter of papaya in different mulch

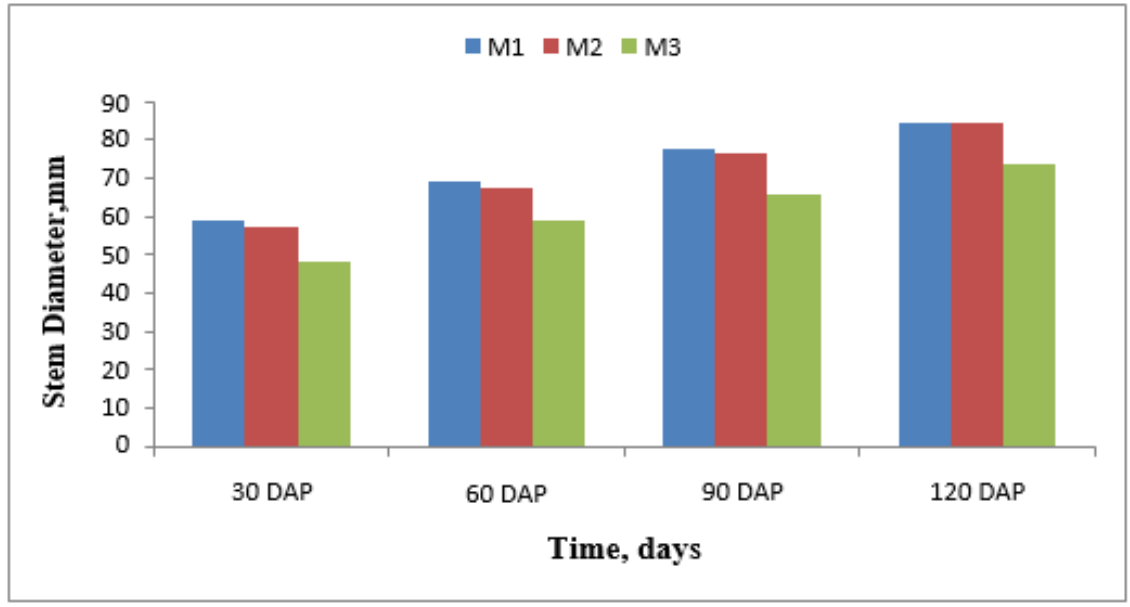

Fig.4 No of leaves of papaya in different mulch

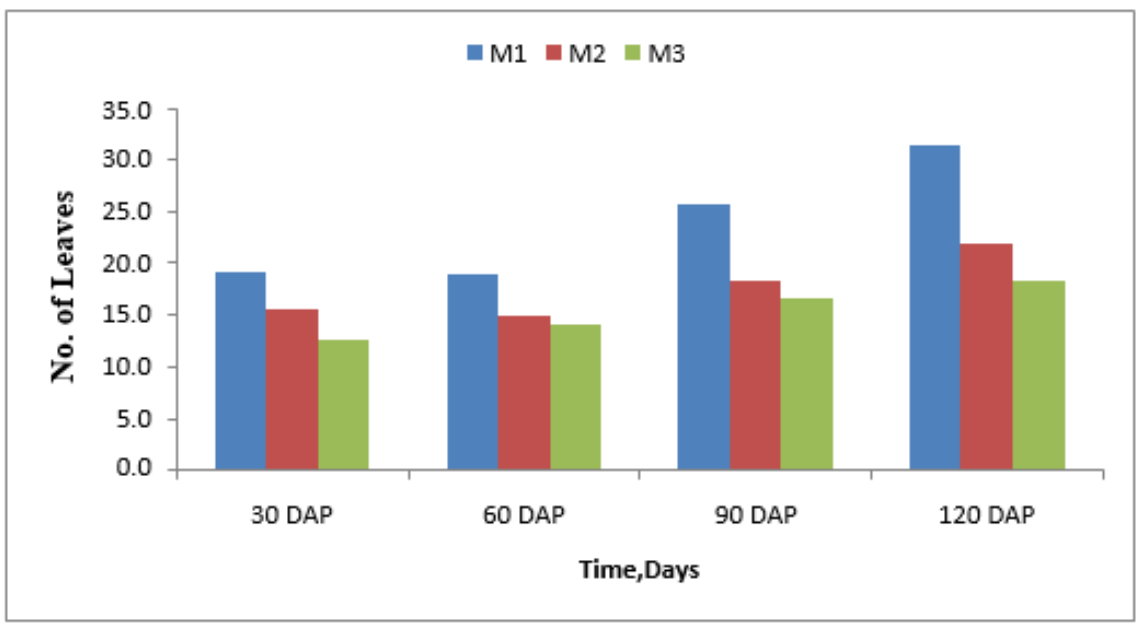


Fig.5 No. of Flower of papaya in different mulch

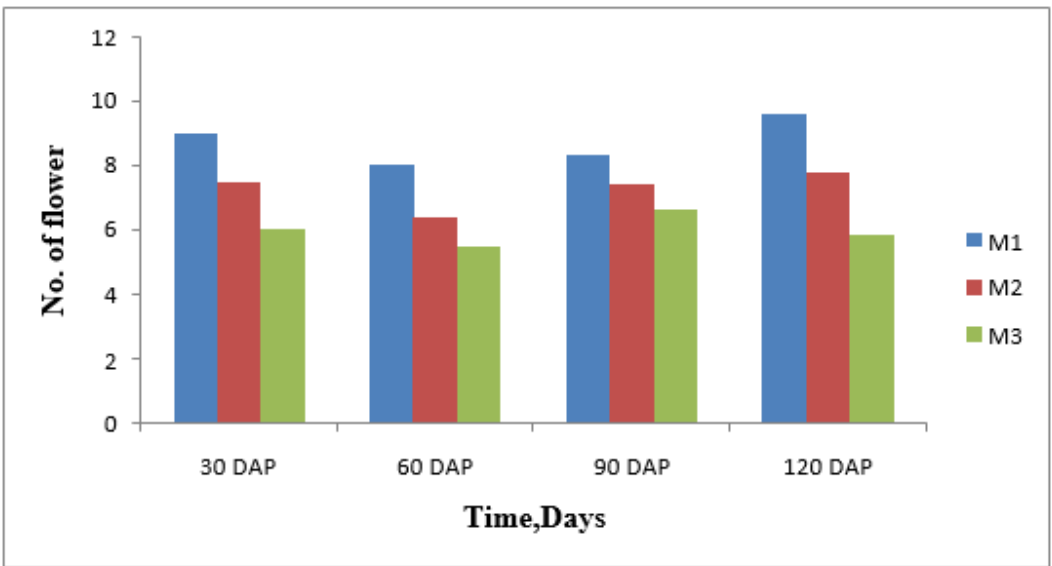

Fig.6 No. of fruit of papaya in different mulch

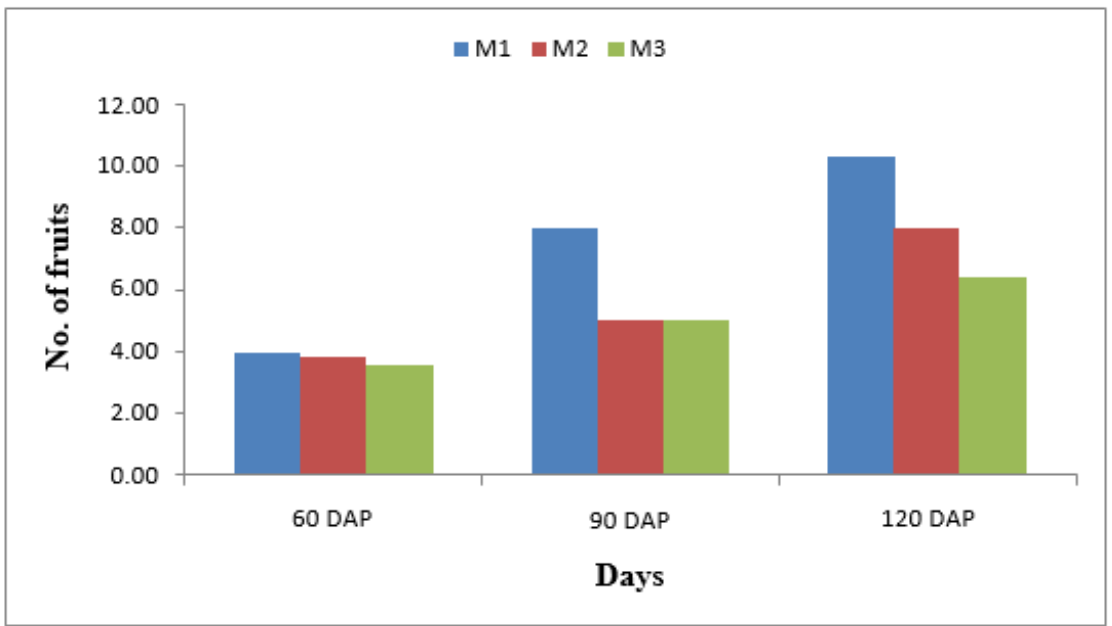

Fig.7 Yield of different variety of papaya in different mulch

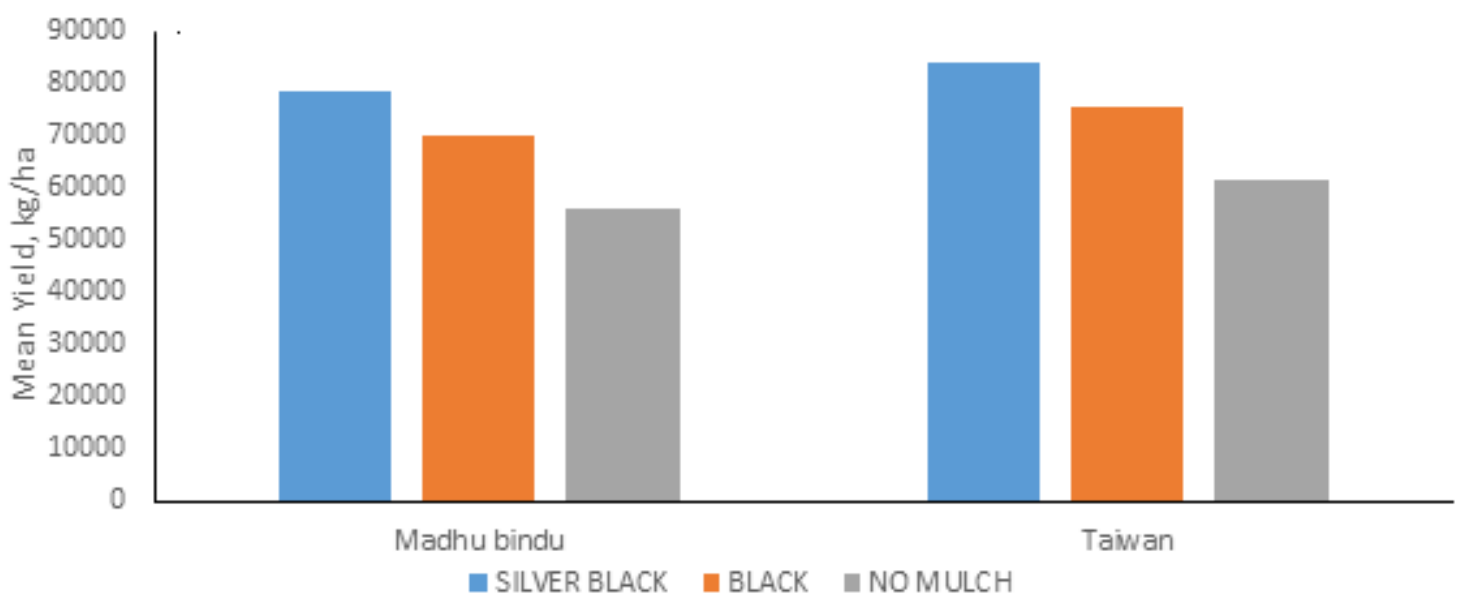




\section{No. of fruits}

The data on number of fruit of papaya plant at different period was influenced by mulch and varieties are presented in figure 6 . The treatment M1 (silver black plastic mulch) gave maximum no. of flower of papaya as 4.00, 8.00 and 10.30 at 60,90 , and 120 DAP respectively. The treatment M3 (no mulch) gave minimum no. of fruit of papaya as 3.60 , 5.00 and 6.40 for 60,90 and 120 DAP respectively.

\section{Yield of crop}

The data on yield of papaya at different period was influenced by mulch and varieties are presented in figure 7 for Madhu bindu variety, the treatment M1 (silver black plastic mulch), M2 (black plastic mulch), M3 (no mulch) gave mean yield of papaya as 78400 $\mathrm{kg} / \mathrm{ha}, 70000 \mathrm{~kg} / \mathrm{ha}, 56000 \mathrm{~kg} / \mathrm{ha}$ respectively. For Taiwan variety, the treatment M1 (silver black plastic mulch), M2 (black plastic mulch), M3 (no mulch) gave mean yield papaya as $84000 \mathrm{~kg} / \mathrm{ha}, 75600 \mathrm{~kg} / \mathrm{ha}, 61600$ $\mathrm{kg} / \mathrm{ha}$ respectively.

\section{Water use efficiency}

The data on water use efficiency for both the varieties and under different mulching treatments are presented in Table 1 . Maximum water use efficiency was found $334.03 \mathrm{~kg} / \mathrm{ha} . \mathrm{mm}$ in silver black plastic mulch treatment and minimum water use efficiency was found $162.12 \mathrm{~kg} / \mathrm{ha} . \mathrm{mm}$ in no mulch treatment of Madhu bindu variety.

In same manner, for Taiwan variety maximum and minimum water use efficiency were as found $357.88 \mathrm{~kg} / \mathrm{ha} . \mathrm{mm}$ in silver black plastic mulch treatment and 17912 $\mathrm{kg} / \mathrm{ha} \mathrm{mm}$ in no mulch treatment respectively. Water saving was found as $31.75 \%$ in mulch condition as compared to no mulch condition.

\section{Economics}

To determine production of papaya, $\mathrm{kg} / \mathrm{plant}$ was calculated as given below. In Madhu bindu variety of papaya in silver black plastic mulch can be grown $28 \mathrm{~kg} /$ plant, black plastic mulch can be grown $25 \mathrm{~kg} / \mathrm{plant}$ and no mulch can be grown $20 \mathrm{~kg} /$ plant. In Taiwan variety of papaya in silver black plastic mulch can be grown $30 \mathrm{~kg} /$ plant, black plastic mulch can be grown $27 \mathrm{~kg} / \mathrm{plant}$ and no mulch can be grown $22 \mathrm{~kg} /$ plant.

The highest and lowest total cost of cultivation was found as Rs. 112322.22 per hectare and Rs. 81490.45 per hectare respectively under treatment of Black mulch and Silver black plastic mulch and The highest and lowest gross income treatment was found as Rs. 840000.00 per hectare and Rs. 700000.00 per hectare respectively under treatment silver black plastic mulch and black plastic mulch. The net return is calculated as per; The highest and lowest net return was found as Rs. 758509.55 per hectare and Rs.587677.8 per hectare respectively under treatment of Silver black plastic mulch and black plastic mulch as shown in below Table 2.

Drip irrigation with mulching is one of the best and latest technologies for efficient utilization of irrigation water. In this approach, yield of Taiwan variety of papaya in silver black plastic mulch is higher than another variety and treatment. Water saving was found as $31.75 \%$ in mulch condition as compared to no mulch condition. Maximum net income was found in silver black plastic mulch in Taiwan variety.

\section{References}

Agrawal, N. and Agrawal, S. (2005). Effect of drip irrigation and mulches on the growth and yield of banana. Indian Journal of Horticulture, 62(3): 238-240. 
Allen, R.; Pereira, L. A.; Raes, D. and Smith, M. (1998). Crop evapotranspiration. FAO Irrigation and Drainage Paper No.56.

Anonymous (2010b). Large scale testing of precision farming technologies in papaya. Report of 6th meeting of Natural Resources Management Joint Sub Committee, April 67, pp 85-89.

Anonymous 2014. Effect of mulch and irrigation level by drip on water use efficiency and yield of water melon. 10th AGRESCO report, CAET, JAU, Junagadh.

Biswas, S. K.; Akanda, A. R.; Rahman, M. S. and Hossain, M. A. (2015). Effect of drip irrigation and mulching on yield, water-use efficiency and economics of tomato. Plant Soil Environment, 61(3): 97-102

Cetin, O. and Uygan, D. (2008). The effect of drip line spacing, irrigation regimes and planting geometries of tomato on yield, irrigation water use efficiency and net return. Agricultural Water Management, 95(8):949-958.

Chaterlan, G. Hernández, (2012). Estimation of the Papaya Crop Coefficients for Improving Irrigation Water Management in South of Havana, Proc. XXVIIIth IHC - IS on Citrus, Bananas and Other Trop. Fruits under Subtrop. Conditions, Eds.: J.-N. Wünsche and L.G. Albrigo, Acta Hort. 928, ISHS 2012

Deshmukh G. and Hardaha MK. (2014). Effect of irrigation and fertigation scheduling under drip irrigateion in papaya. Journal of AgriSearch 1(4): 216-220.

Doorenbos, J. and Pruitt, W. O. 1977. Guidelines for predicting crop water requirements. FAO-ONU, Rome, Irrigation and Drainage Paper No.24 (rev.).

Gulshan Mahajan and Rakesh Sharda (2007). Effect of plastic mulch on economizing irrigation water and weed control in baby corn sown by different methods, African
Journal of Agricultural Research Vol. 2 (1), pp. 019-026, January 2007.

Hamid, H.H., Rajab Larijani, H.R., Agha Alikhani. M., Farahvash. F., and Rashidi, V. (2010). Evaluation of colored plastic mulches in tomato production. International Journal of Agriculture and Crop Sciences, 4(20):1540-1545.

Masri and Razak (1990). Response of papaya (Carica papaya L.) to limited soil moisture at reproductive stage, MARDI ResJ. 18(2) (1990)1:9 1 -196.

Muhammed U.P. Faras Bin, P.V. Sindhu, K. Surendra Gopal, and C. George Thomas (2015). Influence of mulches on rhizosphere microflora, yield and weed competition in okra [Abelmoschus esculentus (L.) Moench], Journal of Tropical Agriculture 53 (1): 70-74, 2015.

Rajbir, S.; Satyendra, K.; Nangare, D. D. and Meena, M. S. (2009). Drip irrigation and black polyethylene mulch influence on growth, yield and water-use efficiency of tomato. African Journal of Agricultural Research, 4 (12):1427-1430.

Ramakrishna, A.; Tam, H. M.; Wani, S. P.and Long, T. D. (2006). Effect of mulch on soil temperature, moisture, weed infestation and yield of groundnut in northern Vietnam. Field Crops Research, 95(2):115-125.

Suresh R. and Saha, D. P. (2004). Effect of mulching and drip irrigation on papaya incalcareous soil of North Bihar. Progressive horticulture. 36(1):76-81.

Verma, M. L.; Thakur, B. C.; and Bhandari, A. R. (2007). Effect of drip irrigationand polyethylene mulch on yield, quality and water-use efficiency of peach cv. July Elberta. Indian Journal of Horticulture, 64(4): 406-409.

\section{How to cite this article:}

Sakariya, K.K., R.M. Satasiya, V.D. Satasiya and Sapariya, P.S. 2018. Performance of Plastic Mulch on Papaya Crop. Int.J.Curr.Microbiol.App.Sci. 7(03): 3243-3251. doi: https://doi.org/10.20546/ijcmas.2018.703.375 